http://jmscr.igmpublication.org/home/ ISSN (e)-2347-176x ISSN (p) 2455-0450

crossref DOI: https://dx.doi.org/10.18535/jmscr/v9i12.24

Journal Of Medical Science And Clinical Research

\title{
Undiagnosed Asymptomatic Bacteriuria and Its Prevalence among Pregnant Women Attending Antenatal OPD: A Cross Sectional Study at State Hospital
}

\author{
Authors \\ Dr Meenakshi Rana ${ }^{1}$, Dr Kamini Randhawa ${ }^{2} *$ \\ ${ }^{1}$ Junior Resident, Department of Obstetrics and Gynaecology, IGMC Shimla \\ ${ }^{2}$ Junior Resident, Department of Anesthesiology, IGMC Shimla \\ *Corresponding Author \\ Dr Kamini Randhawa \\ Junior Resident, Department of Anesthesiology, IGMC Shimla, India
}

\begin{abstract}
Introduction: In pregnant woman the presence of asymptomatic bacteriuria is common without any symptoms and has a prevalence of 2-10\%. When the urine of a asymptomatic pregnant patient is collected and cultured it showed a growth of organism $>=10^{5}$ in asymptomatic bacteriuria. This condition usually progress to other urinary complications and adverse fetal outcomes. Hence it is advised that all the pregnant patients who are asymptomatic should undergo urine culture for screening of asymptomatic bacteriuria.

Methodology: This study was a prospective cross sectional study. All the asymptomatic antenatal patients attending the opd were given sterile urine container and explained the method to collect a midstream urine sample by clean catch method and urine analysis done by microscopy and tested by culture method.

Result: in this study a total of 940 patients without any symptom of urinary tract infection were included. After urine culture out of these patients, 156 patients were found to have asymptomatic bacteriuiria. After the urine culture the most common pathogen isolated was E.coli and second most common isolated pathogen was Klebsiella. Urine culture was followed by drug sensitivity and it showed maximum sensitivity to nitrofurantoin (100\%).

Conclusion: In pregnant women without any symptoms urine culture showed asymptomatic bacteriuria with a prevalance of $16.5 \%$. When left untreated Urinary tract infection may lead to serious complications in mother as well as in fetus. Most common pathogen found was E.coli and highest drug sensitivity was found for nitrofurantoin. Hence urine culture test should be done in all asymptomatic pregnant patients despite period of gestation.
\end{abstract}

\section{Introduction}

The existence of pathogen in the urine sample of a patient without any symptoms of urinary tract infection is called as asymptomatic bacteriuria. During pregnancy there is decrease in immunity which lead to development of pathogen in urine both commensal and non commensal organisms. Other reason is increased plasma volume which in turn decreases the urine concentration and decrease in the renal threshold lead to glycosuria 
which also favours development of pathogens. Worldwide incidence of asymptomatic bacteriuria lies between 2-10\%.

In this condition when urine culture is done it showed significant growth of bacteria that is $>=10^{5}$ bacteria per $\mathrm{ml}$. When left untreated asymptomatic bacteruia may progress to symptomatic bacteriuria leading to seroius complications of such as pyelonephritis and obstetric complications such as premature birth, pre-eclamptia, anaemia, premature rupture of the membrane, and postpartum endometritis, complications in neonates such as low birth weight, increased neonatal mortality may also occur.

Hence is has been suggested that routine screening of antenatal patients attending the opd should be done for asymptomatic bacteriuria and it should treated before its progression to adverse sequelae. However routine screening of antenatal patients in our country or in other developing countries is not done because of cost factor and long duration of results such patients may be lost to follow up hence on their visit urine routine microscopy is done which may indicate presence of glucose and protein suggesting further testing with urine culture and sensitivity in such patients.

Adverse outcomes mat be seen if asymptomatic bacteriuria is left untreated and despite these complications adequate screening and treatment of this condition is not done accuratly.

This study will provide the knowledge to focus on screening, assessing the risk factors, testing for antimicrobial susceptibility and need for antimicrobial treatment.

\section{Material and Methods}

The design setting of our study was prospective cross sectional study. In this study about 940 antenatal patients who attended the opd from $1^{\text {st }}$ august 2019 to $1^{\text {st }}$ February 2019 were included. Inclusion criteria of our study was asymptomatic pregnant patients without any sign and symptom of urinary tract infection, aged between 18-45 years, with singleton pregnancy and with history of preterm labour in the previous pregnancy.
Exclusion criteria was previous history of UTI, treated case of UTI, known case of urinary tract malformation, known case of renal disease or SLE or chronic disorder.

Our study included all the pregnant patients who came in to the opd for routine antenatal checkup were included in this study after taking into consideration of the inclusion criteria and those unfit for study were excluded at the time of enrollment. All the enrolled patients were explained thoughly about the study and informed consent was taken. All patients were advised to collect $20 \mathrm{cc}$ of midstream clean catch urine sample in a sterile container, collected samples were then transported to testing laboratory. Data hence collected was tabulated and analysed.

\section{Results}

A total of 940 pregnant patients without symptoms were enrolled in this study. Out of these 940 enrolled pregnant patients, only 156 were found to be positive on urine culture for significant bacteriuria, showing a prevalence of $16.5 \%$. About $20.2 \%$ patients were found to be in the age group of 26-30 years. Maximum patients were in first trimester with a prevalence of $18.6 \%$ culture positive patients. Most common organism found in urine culture was E.coli with a prevalence of $55.7 \%$ and second common pathogen was klebsiella with a prevalence of $27.5 \%$.

Table 1: Prevalence with age

\begin{tabular}{|l|c|c|c|}
\hline Age group & $\begin{array}{c}\text { Number of } \\
\text { patients }\end{array}$ & $\begin{array}{c}\text { Culture } \\
\text { positive }\end{array}$ & Percentage \\
\hline $18-25$ & 256 & 44 & $17.1 \%$ \\
\hline $26-30$ & 336 & 68 & $20.2 \%$ \\
\hline $31-35$ & 264 & 41 & $15.5 \%$ \\
\hline $36-40$ & 46 & 2 & $4.3 \%$ \\
\hline$>40$ & 38 & 1 & $2.6 \%$ \\
\hline
\end{tabular}

Table 2: Prevalence in each trimester of pregnancy

\begin{tabular}{|l|c|c|c|}
\hline Trimester & $\begin{array}{c}\text { Number of } \\
\text { patients }\end{array}$ & $\begin{array}{c}\text { Culture } \\
\text { positive }\end{array}$ & Percentage \\
\hline First & 419 & 78 & $18.6 \%$ \\
\hline Second & 306 & 55 & $17.9 \%$ \\
\hline Third & 215 & 23 & $10.6 \%$ \\
\hline
\end{tabular}


Table 3: Prevalence of pathogen in culture

\begin{tabular}{|l|c|c|}
\hline Pathogen & Number & Percentage \\
\hline E.Coli & 87 & $55.7 \%$ \\
\hline Klebsiella & 43 & $27.5 \%$ \\
\hline Staphylococcus aureus & 12 & $7.6 \%$ \\
\hline Proteus & 9 & $5.7 \%$ \\
\hline Pseudomonas & 5 & $3.2 \%$ \\
\hline
\end{tabular}

\section{Discussion}

To ensure the proper health of antenatal patients and newborn babies adequate health care services should be provided. It has been seen that urine strip test is done for urine analysis in routine and urine culture test is not done for screening in pregnant woman. For treatment of such patients usually only empirical antibiotics are used.

In our study the prevalence was calculated and is found to be $16.5 \%$ which was lower when compared to the studies done in Benin, Nigeria (45.3\%), Sagamu, Nigeria (23.9\%) and higher a compared to studies done in Ghana $(7.3 \%)$ and Euthopia (7\%). It is found in our study that the prevalence of asymptomatic bacteriuira in the age group of 26-30 year (20.2\%) was higher followed by in age group $31-35$ year $(15.5 \%)$. our results were compared to other studies were found simillar with them. Maternal age more than 35 was also considered as a risk factor due to multiparity such ptients may acquire infection repeatdly. in this study the most common pathogen found was E.Coli (55.7\%) followed by klebsiella $(27.5 \%)$ due to the stasis of urine and poor genital hygiene.

In this study it also found that drug sensitivity was done it is found to be $100 \%$ sensitive to nitrofurantoin. Hence it is suggested that urine culture should be done in all antenatal patients as tool for diagnosis of asymptomatic bacteriuria to ensure adequate treatment of the patient and prevention of major complications in both mother and newborn.

\section{Conclusion}

Our study showed a $16.5 \%$ prevalence of asymptomatic bacteriuria in asymptomatic pregnant patients which was higher than few studies done in Ghana and Euthopia. This is also a matter of great concern because urinary tract infection may lead to some serious complications in mother and also in fetus. Most common pathogen found was E.coli and highest drug sensitivity was found for nitrofurantoin. Hence it is adviced that urine culture test is to be done in all asymptomatic patients who attend the opd for screening of asymptomatic bectriuria.

\section{References}

1. Patterson TF, Andrriole VT. Bacteriuria in pregnancy. Infect Dis Clin North Am. 1987; 1:807-822.

2. Lucas MJ, Cunningham FG. Urinary tract infection in pregnancy. Clinical Obstet. Gynaecol. 1993; 36:555-568.

3. Olusanya O, Ogunledum A, Fakoya TA. Asymptomatic significant bacteriuria among pregnant and non pregnant women in Sagamu, Nigeria. WAJM 1993; 12(1):27-33.

4. Turpin CA, Minkah B, Danso KA, Frimpong EH. Asymptomatic bacteriuria in pregnant women attending antenatal clinic at Komfo Anokye Teaching Hospital, Kumasi, Ghana. Ghana Med J 2007; 41(1):26-29.

5. Gabre-Selassie S. Asymptomatic bacteriuria in pregnancy; epidemiological clinical and microbiological approach. Ethiop Med J 1998; 36:185-192.

6. Akerele P, Okonofua JA. Prevalence of asymptomatic bacteriuria among pregnant women in Benin City, Nigeria J Obstet Gynaecol 2001; 21(2):141-144.

7. Givler DN, Amy G. Asymptomatic bacteriuria. In: Stat Pearls [Internet]. Treasure Island. Stat Pearls Publishing; 2020. Available from: https: //www.ncbi.nlm.nih.gov/books/NBK4418 $48 /$.

8. Jayalakshmi J, Jayaram VS. Evaluation of various screening tests to detect asymptomatic bacteriuria in pregnant 
women. Indian J Pathol Microbiol. 2008; 51(3): 379-81.

9. Azami M, Jaafari Z, Masoumi M, Shohani M, Badfar G, Mahmudi L, et al. The etiology and prevalence of urinary tract infection and asymptomatic bacteriuria in pregnant women in Iran: asystematic review and meta-analysis. BMC Urol. 2019; 19(1): 1-15.

10. Ullah MA, Barman A, Siddique MA, Haque AK. Prevalence of asymptomatic bacteriuria and its consequences in pregnancy in a rural community of Bangladesh. Bangladesh Med Res Counc Bull. 2007 Aug; 33(2): 60-4. 